\title{
食道静脈瘤直達手術後胃十二指腸出血例の検討
}

\author{
東京大学医学部第 2 外科 \\ 梅北 信孝* 出月 康夫 三條 健昌 川崎 誠治 \\ *現所属 山梨医科大学第 2 外科 (主任：上野 明教授)

\section{GASTRODUODENAL HEMORRHAGE AFTER NON-SHUNTING PROCEDURES FOR ESOPHAGEAL VARICES}

\section{Nobutaka UMEKITA*, Yasuo IDEZUKI, Kenshou SANJOU and Seiji KAWASAKI} \\ The 2nd Department of Surgery, Faculty of Medicine, University of Tokyo \\ *The 2nd Department of Surgery, Yamanashi Medical College \\ 1964年より1985年までに施行した種々の食道静脈瘤直達手術441症例について術後遠隔時の胃十二 \\ 指腸出血率を検討した。術後出血例は70例（16\%）で，うち胃十二指腸出血は44例（63\%）であり， \\ 累積胃十二指腸出血率は 5 年 $9.7 \%, 10$ 年 $18.3 \%, 15$ 年 $20.1 \%$ であった。累積胃十二指腸出血率を各種 \\ の直達手術術式別に分けて検討したが有意差はなかった。 \\ Child 分類による肝機能別, 吐血歴の有無別でも各群間に有意差はなかったが, 疾患別では有意に肝 \\ 外門脈閉塞症例での出血率が高かった。血行遮断の範囲の異なる各直達手術間で出血率に有意差のな \\ いことから，血行遮断の範囲は術後遠隔時の胃十二指腸出血率に影響を扣よぼさないるのと考えられ
} た.

索引用語：食道静脈瘤直達手術, 胃十二指腸出血, 胃炎出血, 食道離断術

\section{緒 带}

本邦では食道静脈瘤患者に対し, 食道離断術などの 直達手術や選択的シャント手術が施行されて执り良好 な成績が報告されている11. 生た近年内視鏡的硬化療 法の発達に伴い肝機能不良患者の治療成績も向上して きている.一方門脈圧六進症患者の上部消化管出血に は胃十二指腸病変のしめる頻度も高(2) 6), 食道静脈 瘤手術後の上部消化管出血にしめる胃十二指腸出血, 特に胃炎出血は術後経過観察上注意しなければならな い.この胃炎出血の原因はよく解明されていないが門 脈圧亢進による胃壁血行動態の異常が関与すると考え られて拈り 2)7)8), 食道離断術と広範な血行遮断を行う ことによる胃壁血行動態の改変がこの胃十二指腸出血 率に影響を及ぼすことが推測される。実際に血行遮断 により胃十二指腸出血率が増加するのかを検討した報 告はない.

$<1986$ 年11月12日受理 >別刷請求先：梅北 信孝 干409-38 山梨県中巨摩郡玉穂町下河東1110 山梨医 科大学第 2 外科
今回1964年より1985年までに施行した種々の食道静 脈瘤直達手術 473 症例について術式や肝機能などが術 後遠隔時の胃十二指腸出血の頻度に影響を及ぼすかど らかを retrospective に検討し直達手術の胃粘膜に与 学影響につき考察したので報告する。

\section{対 象}

1964年より1984年12月までに東京大学第 2 外科学教 室で直達手術を施行した食道静脈瘤症例は473例（男 332例，女141例)である。疾患は肝硬変症343例，特発 性門脈圧亢進症88例, 肝外門脈閉塞症36例, その他 6 例である。術式は 1 期的経胸経腹的食道離断術（経胸 経横隔膜的食道離断術を含む)（東大第 2 外科法 1 期） 120 例， 2 期分割経胸経腹的食道離断術(東大第 2 外科 法 2 期) 171例, 経胸食道離断術96例, 経腹的食道離断 術（胸骨繸切開による食道離断術症例を含も）15例， 単純食道離断術 (Walker 法) 37例, 脾摘兼胃上部血行 遮断術（Hassab 法）34例である（表 1 ）. 主として東 京大学第 2 外科法を施行している.肝機能が良好なら ば東大第 2 外科法 1 期を，東大第 2 外科法 2 期は肝機 
表 1 食道静脈瘤直達手術例

東大第 2 外科 $1964 / 1 \sim 1984 / 12$

\begin{tabular}{|c|c|c|c|c|c|c|}
\hline & LC & $\mathrm{IPH}$ & EHPO & 日位血 & その他 & 計 \\
\hline Walker & $16(1)$ & 13 & 7 & 1 & 0 & $37(1)$ \\
\hline 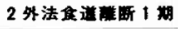 & $82(3)$ & 22 & 16 & $\mathbf{0}$ & 0 & $120(3)$ \\
\hline 2 外法食道淮断 2 期 & $129(3)$ & 34 & 5 & 3 & 0 & $171(3)$ \\
\hline 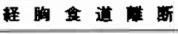 & $77(17)$ & 10 & 8 & 0 & 1 & $96\langle 17\rangle$ \\
\hline 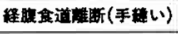 & 4 & 0 & 0 & 0 & 0 & 4 \\
\hline$H \quad(\mathrm{E} \in \mathrm{A})$ & 3 & 1 & 0 & 0 & 0 & 4 \\
\hline 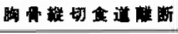 & 5 & 1 & 0 & 0 & 1 & 7 \\
\hline Hassab & $27(2)$ & 7 & 0 & 0 & 0 & $34(2)$ \\
\hline 部 & $343(26)$ & 88 & 36 & 4 & 2 & $473(26)$ \\
\hline
\end{tabular}

能不良例に対し原則として経胸手術を先に行ってい る. 経胸的食道離断術は肝機能が不良で腹部操作を追 加できなかった症例に対するものである. Walker 法 は初期の症例であり, Hassab 法は原則として静脈瘤 が軽度で食道下部に限局している症例もしくは胃静脈 瘤のみの症例に施行している。

手術死亡は全例肝硬変症例でWalker 法 1 例 $(2.7 \%)$, 東大第 2 外科法 1 期 3 例 (2.5\%), 東大第 2 外科法 2 期 3 例 (1.7\%), 経胸的食道離断術17例 (18\%), Hassab 法 2 例（5.9\%）であった。

手術死亡26例と，原疾患その他 6 例をのぞく441例を 対象として遠隔時上部消化管出血例を検討した。出血 源は原則として内視鏡検査により診断したが吐下血後 1 週間をすぎ検查した症例で静脈瘤, 潰瘍のない症例 は胃炎出血として集計した。な祅肝癌末期，肝不全末 期に消化管出血をきたした症例は出血例から除外し た。胃炎，招よび胃十二指腸潰瘍出血を胃十二指腸出 血としてまとめた。粗出血率は出血例数/耐術例数とし た。累積出血率は，ある区間の始めに生存した例数よ りその区間の死亡例, 脱落例沶よび途中経過例数の 1 / 2を減じてこれを母数としその区間の出血例数を除い て区間出血率を算出した。これを 1 から減じた区間非 出血率を乗じて累積非出血率を算定し，これを再び 1 から減じたものを累積出血率とした。 各群間の粗出血 率の検定は $\chi^{2}$ 検定によった. 各群間の累積出血率の差 の検定は generalized Wilcoxon 法によった。

\section{成 積}

1) 術後出血例は70例 (男58例，女12例) で粗出血率 は16\%であった. 出血源は胃炎38例, 食道静脈瘤18例, 胃十二指晹潰瘍 6 例，不明 8 例であった（表 2).

累積胃十二指腸出血率は 5 年 $9.7 \%, 10$ 年 $18.3 \%, 15$ 年20.1\%であった（図1）。
表 2 出血源

\begin{tabular}{c|c|c|c|c}
\hline 胃炎 & 食道静脈瘤 & 胃十二指腸潰瘍 & 不明 & 計 \\
\hline 38 & 18 & 6 & 8 & 70 \\
$(9 \%)$ & $(4 \%)$ & $(1 \%)$ & $(2 \%)$ & $(16 \%)$ \\
\hline
\end{tabular}

図 1 累積胃十二指腸出血率 ( \pm s.e. )

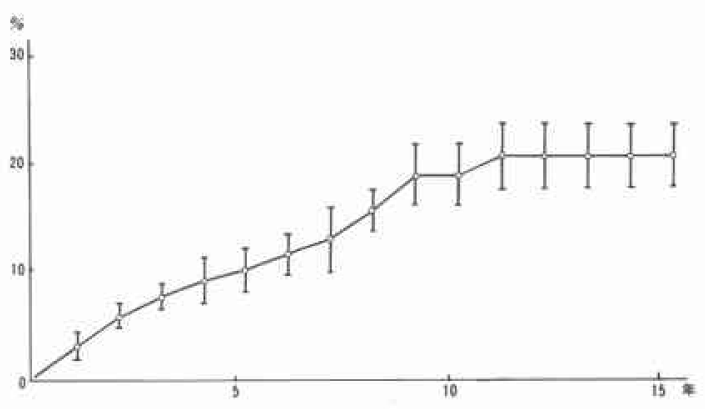

2）術式別の術後胃十二指腸粗出血率は, Walker 法 $14 \%$, 経胸的食道離断術 $6 \%$, 東大第 2 外科法 1 期 $11 \%$, 東大第 2 外科法 2 期 $10 \%$, Hassab 法 $6 \%$, 経腹 的食道離断術 $14 \%$ であった，各群間に有意差はなかっ た（表 3 ).

累積胃十二指腸出血率をみると Walker 法は 5 年 $6.9 \%, 10$ 年 $13.4 \%, 15$ 年 $13.4 \%$, 経胸的食道離断術は 5 年 $5.2 \%, 10$ 年 $19.6 \%, 15$ 年 $19.6 \%$, 東大第 2 外科法 1 期は 5 年 $11.1 \%, 10$ 年 $14.8 \% ， 15$ 年 $14.8 \%$ ，東大第 2 外科法 2 期は 5 年 $11.3 \%, 10$ 年 $25.1 \%, 15$ 年 $25.1 \%$, Hassab 法は 5 年 $5.1 \%, 10$ 年 $32.2 \%$ であったが，各群 間に有意差はなかった（図 2，3）。

3) Child 分類による肝機能別に術後胃十二指腸出 血をみると，粗出血率は Child A 群 $12 \%$, Child B 群 $9 \%$, Child C 群 $8 \%$ であり各群間に有意差はなかっ た（表 4 ).

累積胃十二指腸出血率は Child A 群では 5 年 $8.9 \%$, 10 年 $18.4 \%, 15$ 年 $21.0 \%$, Child B 群では 5 年 $9.6 \%$, 10 年 $14.5 \%, 15$ 年 $14.5 \%$, Child C 群では 5 年 $12.2 \%$, 10 年 $29.7 \% ， 15$ 年 $29.7 \%$ あたが各群間に有意差はな かった（図4).

4）疾患別に術後胃十二指腸出血をみると,粗出血率 は肝硬変症例 $9 \%$, 特発性門脈圧六進症例 $7 \%$, 肝外 門脈閉塞症例 $28 \%$ であり $1 \%$ の危険率で有意に肝外門 脈閉塞症例の出血率が高かった（表 5 ).

累積胃十二指腸出血率は肝硬変症例では 5 年 $9.5 \%$, 10 年 $17.8 \%, 15$ 年 $17.8 \%$, 特発性門脈圧元進症例は 5 年 $4.8 \%, 10$ 年 $12.9 \%, 15$ 年 $12.9 \%$, 肝外門脈閉塞症例 
表 3 手術術式別にみた胃十二指腸出血

\begin{tabular}{c|c|c|c|c|c|c|c}
\hline 手術術式 & Walker & 経胸 & 1 期 & 2 期 & Hassab & 経腹 & 計 \\
\hline $\begin{array}{c}\text { 出血例数/耐術例数 } \\
\text { (粗出血率) }\end{array}$ & $\begin{array}{c}5 / 35 \\
(14 \%)\end{array}$ & $\begin{array}{c}5 / 78 \\
(6 \%)\end{array}$ & $\begin{array}{c}13 / 117 \\
(11 \%)\end{array}$ & $\begin{array}{c}17 / 165 \\
(10 \%)\end{array}$ & $\begin{array}{c}2 / 32 \\
(6 \%)\end{array}$ & $\begin{array}{c}2 / 14 \\
(14 \%)\end{array}$ & $\begin{array}{c}44 / 441 \\
(10 \%)\end{array}$ \\
\hline
\end{tabular}

図 2 累積胃十二指腸出血率（土s.e.）(術式別 1)

○经

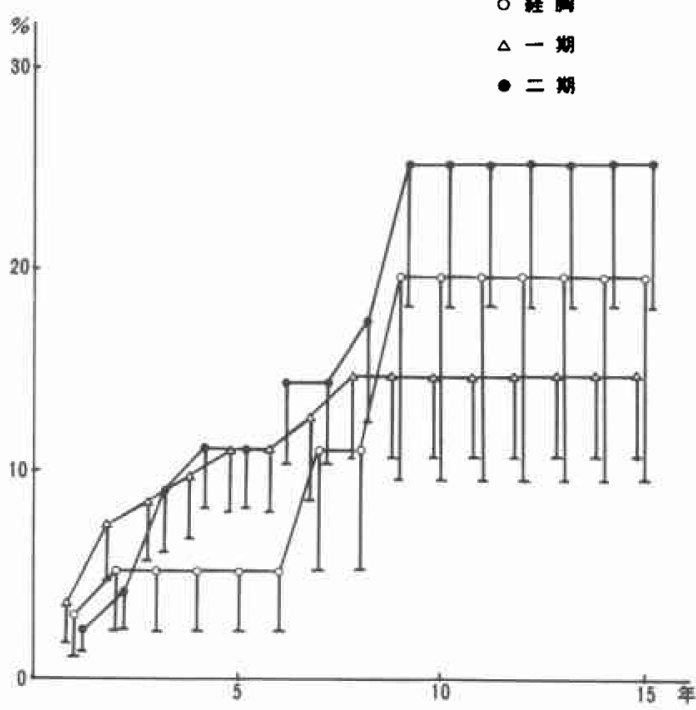

表 4 Child 分類別にみた胃十二指腸出血

\begin{tabular}{c|c|c|c|c}
\hline Child 分類 & A & B & C & 計 \\
\hline $\begin{array}{c}\text { 出血例数/耐術例数 } \\
\text { (粗出血率) }\end{array}$ & $\begin{array}{c}19 / 157 \\
(12 \%)\end{array}$ & $\begin{array}{c}16 / 172 \\
(9 \%)\end{array}$ & $\begin{array}{c}9 / 112 \\
(8 \%)\end{array}$ & $\begin{array}{c}44 / 441 \\
(10 \%)\end{array}$ \\
\hline
\end{tabular}

は 5 年 $22.4 \%, 10$ 年 $31.8 \%, 15$ 年 $38.3 \%$ あり $1 \%$ の 危険率で有意に肝外門脈閉塞症例の出血率が高かった (図 5 ).

5）術前吐血歴の有無による術後胃十二指腸出血を みると，粗出血率は吐血歴のある症例では $11 \%$, 吐血 歴のない予防手術症例では $7 \%$ \%すり各群間に有意差 はなかった（表 6 ）.

累積胃十二指腸出血率は吐血歴のある群では 5 年 $10.8 \%, 10$ 年18.6\%, 15年20.8\%, 予防手術症例では 5 年 $7.2 \%, 10$ 年 $20.1 \%, 15$ 年 $20.1 \%$ であり各群間に有 意差はなかった（図6）。

\section{考察}

食道静脈瘤術後の上部消化管出血に胃十二指腸出血 の頻度の高いことはよく知られている，門脈圧立進症 研究会の報告によれば1)門脈王非下降術である選択的 シャント術症例の $5.5 \%$, 直達手術症例の $3.2 \%$ に胃十
図 3 累積胃十二指腸出血率（土s.e.）(術式別 2)

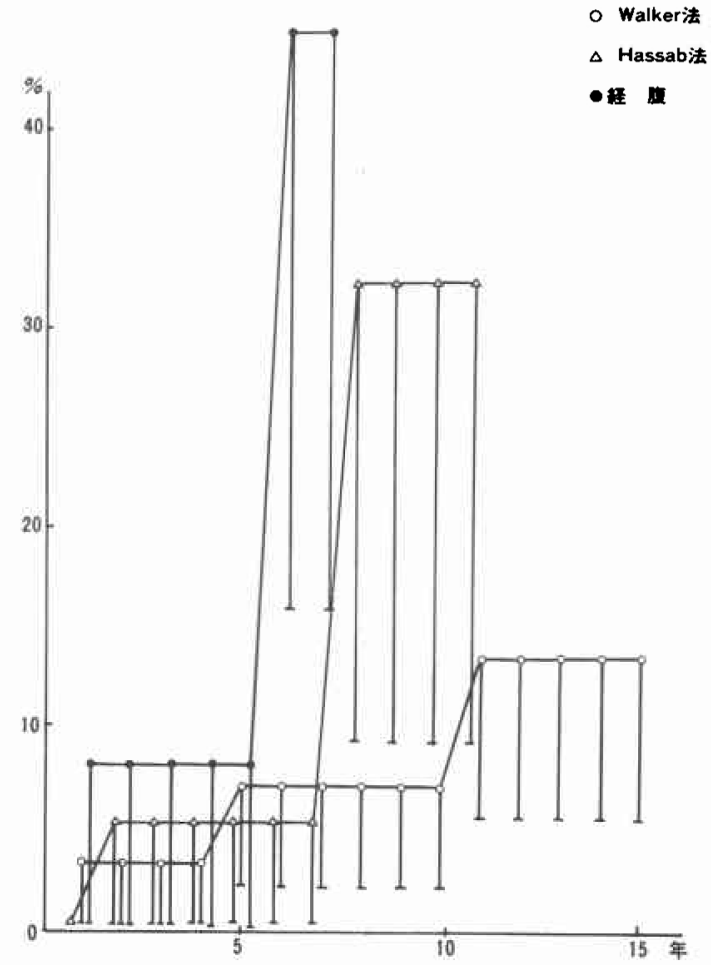

图 4 異秷胃十二指腸出血事 (Child 分類別)

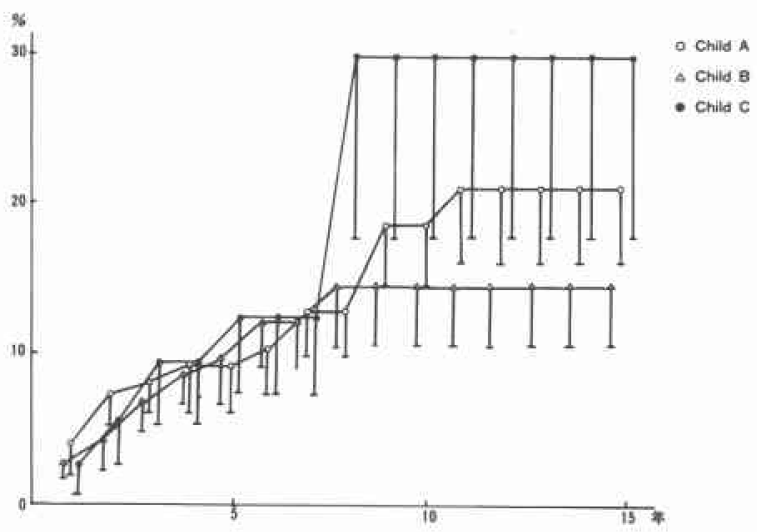

二指腸出血が認められ再発出血に占める頻度はそれぞ れ $42.4 \% ， 30.9 \%$ とっている。この統計では出血源 不明症例を静脈瘤出血として扱っているため実際には 
表 5 原疾患別にみた胃十二指腸出血

\begin{tabular}{c|c|c|c|c}
\hline 原疾患 & 肝硬変症 & 特発性門脈圧立進症 & 肝外門脈閉塞症 & 計 \\
\hline $\begin{array}{c}\text { 出血例数/贆術例数 } \\
\text { (粗出血率) }\end{array}$ & $\begin{array}{c}28 / 317 \\
(9 \%)\end{array}$ & $6 / 88$ & $10 / 36$ & $44 / 441$ \\
\hline
\end{tabular}

図 5 累積胃十二指腸出血率（土s.e.）(原疾患別）

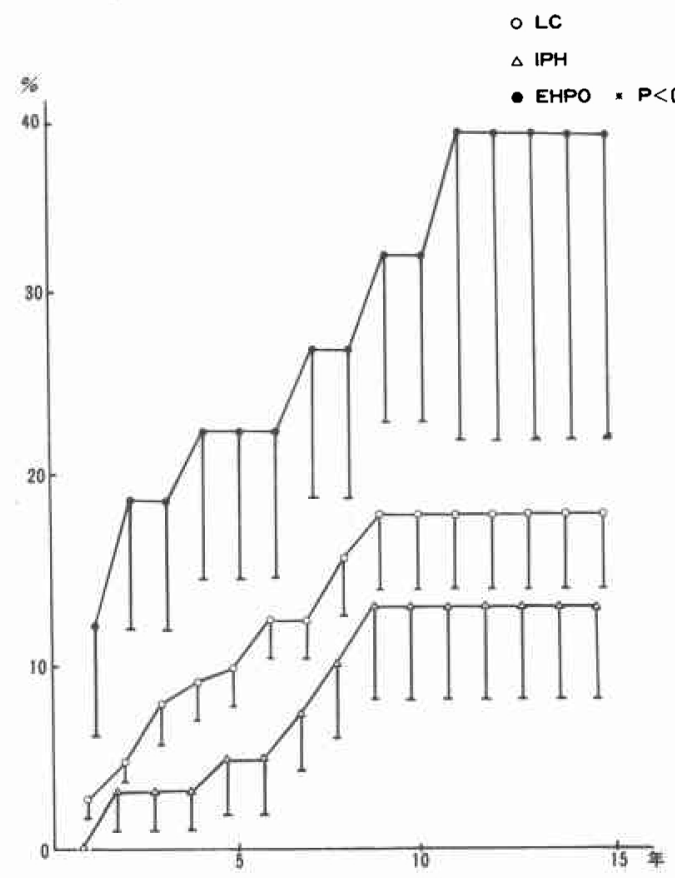

LC : Liver Cirrhosis

IPH : Idiopathic Portal Hypertention

EHPO : Extra Hepatic Portal vein Obstruction

表 6 吐血歴の有無による胃十二指腸出血

\begin{tabular}{c|c|c|c}
\hline 吐血歴 & + & - & 計 \\
\hline $\begin{array}{c}\text { 出血例数/耐術例数 } \\
\text { (粗出血率) }\end{array}$ & $\begin{array}{c}35 / 306 \\
(11 \%)\end{array}$ & $\begin{array}{c}9 / 135 \\
(7 \%)\end{array}$ & $\begin{array}{c}44 / 441 \\
(10 \%)\end{array}$ \\
\hline
\end{tabular}

胃十二指腸出血の占める頻度はさらに高くなると思わ れる.門脈圧下降手術である portocaval shunt は肝性 脳症, 肝不全の発生頻度が高く本邦では行われなく なっているが portocaval shunt においては術後の胃 十二指腸出血が稀であるとする報告がある ${ }^{910)}$. 逆に portocaval shunt 後に胃十二指腸潰瘍の発生頻度が高 率になるとしこのことが術後成績を悪化する因子とな るとする報告もある ${ }^{11}$.

元来門脈王六進症患者の上部消化管出血にしめる胃 十二指腸病変の割合は $25 \%$ 74\%と報告されてお

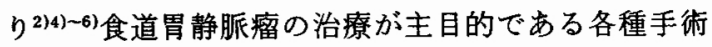

図 6 累積胃十二指腸出血率（土s.e.）(吐血歴の有無 別)

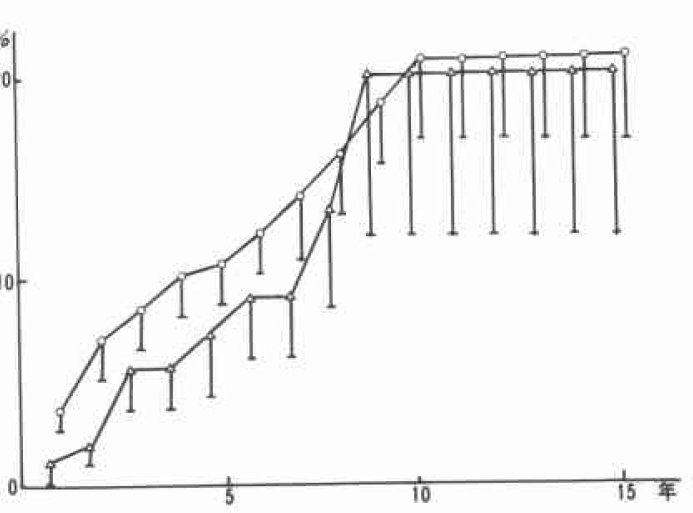

後に胃十二指腸出血がみられたとしても, 手術によっ てその頻度が高くなったかどらかを判断することは難 しい.

門脈圧亢進症におけるこの胃十二指腸病変の発生因 子としては，胃酸刺激物質の肝での不活化の障害によ る胃酸分泌の亢進説 ${ }^{11)}$, 胆汁酸による胃液中和作用の 低下説3，などがあるが門脈圧え進による胃腸壁の血 行障害が原因であるとの見解が多(2)7)8). 食道静脈瘤 に対する手術によりこの胃壁血行動態がどのようにか わるのかは解明されていない。直達手術においては側 副血行路の遮断により一時的な門脈圧六進が起こり胃 壁血行動態が悪化することは推測されるが, 胃壁血行 動態と胃炎出血の相関性については未解決の問題が多 い. 東大第 2 外科法による食道離断術の胃粘膜に影響 をおよほすす因子として,1. 側副血行路の遮断による門 脈系のらっ血の増強に伴ら胃壁血行動態の悪化, 2. 動 脈血行遮断による胃粘膜虚血, 3. 迷走神経切離による 胃液酸度の低下の 3 点が考えられる，1，2 は防御因 子の低下の方向に働き，3攻撃因子の減弱の方向に

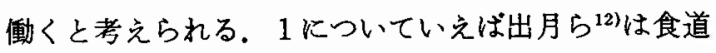
静脈瘤を形成する側副血行路は門脈圧元進症における 側副血行路静脈系の大きな capacitance の中ではは んの一部にすぎずこの遮断によっても門脈仕は変化し ないと述べている。また脾摘や動脈血行遮断によって 
門脈への血流量は減少し門脈圧減少の方向へ動く。た と定実際に門脈圧が一時的に上昇したとしてもほかの 側副血行路の開大によって，長期に観察すれば門脈圧 はもとにもどるであろう。したがって側副血行路の遮 断による胃粘膜に対する影響はあるとして子短期間に かざられる．2つの動脈血行遮断による影響は門脈圧 六進症においては検討されていないが，選択的迷走神 経切離時の動脈血行遮断に伴う胃粘膜血流の測定の報 告によれば術後 4 〜 週までは著明に減少するがその 後は回復してもとにもどるとされる ${ }^{13)}$. 左胃動脈, 短胃 動脈系の遮断により術直後は胃粘膜の血流は低下する が, 右胃動脈, 右胃大網動脈の血流の増加によって代 償されるものと考えられる。

したがって東大第 2 外科法に括ける胃壁血流の改変 による胃粘膜の防御因子の低下はほぼ 1 力月程度にか ぎられるであろ5。 それ以後では 3 の迷走神経切離に 上る攻撃因子の低下のみが手術の影響として残るもの と考充られる. 術後 1 力月以内の早期出血は, 1 と 2 の防御因子の低下が関与すると考克られ，この防御因 子の低下は血行遮断の範囲が広い、ど大きく出血率が 高まると考えられる。実際この早期出血は 3 例 $(0.6 \%)$ ありいずれも血行遮断の範囲の広い東大第 2 外科法 1 期であった ${ }^{14)}$. 河野ら ${ }^{15)}$ む経腹的食道離断術, 経胸的食 道離断術, 2 期分割東大第 2 外科法に打いて術後 1 力 月では経腹的食道離断術の潰瘍合併率が高く 1 期手術 による広範な血行遮断の影響であろうと述べている。

Hassab \& Hassab 法術後合併症として胃炎出血死を 報告しているが16)，血行遮断範囲が広すぎたためであ るとしている。

一方術後 1 カ月以後の胃炎出血は手術の影響の少な い, 門脈圧六進症自体に合併する出血であると考学ら れる.今回は遠隔時の胃十二指腸出血率を検討したが， 食道胃血行遮断の範囲や迷走神経への操作の異なる各 種の直達手術において胃十二指腸出血率に統計的に有 意差を認めなかった。単純食道離断であるWalker 法 と最も血行遮断の範囲の広、食道離断術である東大第 2 外科法 1 期とで比較しても15年累積胃十二指腸出血 率はそれぞれ $13.4 \% ， 14.8 \%$ と有意差はなかった。

今回の検討は retrospective な検討であり静脈瘤の 程度や肝機能など病態に応じて術式が選択されている ためこの胃十二指腸出血率には，㴗的要因も影響を およぽして可能性も考えられる。

従来の報告によれば門脈圧方進症の胃病変の程度 は, 門脈圧や, 血清アルブミン值, ビリルビン值など
の肝機能検查などとは相関がないとされてい

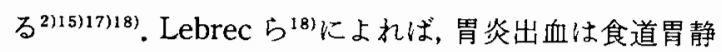
脈瘤の大きさのみに関連があったという。われわれの 成績でも胃十二指腸出血率は Child 分類間で有意差は なかった。しかし疾患別にみると有意に肝外門脈閉塞 症で胃十二指腸出血率が高かった。肝外門脈閉塞症は 肝機能良好な症例が多くまた東大第 2 外科法 1 期手術 例が大部分を占めるが上記のようにこのことが直接に 影響するとは考学にくい，また肝外門脈閉塞症例は肝 硬变症や特発性門脈圧方進症例と比較して門脈圧が高 い傾向にあったが，肝外門脈閉塞症例の中で再出血例 と非出血例の門脈王には差がなかった ${ }^{199}$. 肝外門脈閉 塞症例は小児例を多く含むため成人例と胃粘膜攻繋因 子の状態が異なることや，長期の観察例が多いことな ぞが関係するのかもしれない，今後検討を要する問題 と思われる。

また出血歴の有無です術後胃十二指腸出血率を検討 した．出血歴のない予防手術症例においては静脈瘤の 程度や, 門脈系のコンプライアンスの低下の程度が軽 度であるために手術時まで出血がなかったとも考兄ら れるが，この場合術後の出血率も叶血歴のある症例上 り低いことが予想される。 今回の検討では予防手術症 例と, 緊急, 待期手術症例で術後出血率には有意差は なかった。これは予防手術症例も門脈圧六進症研究会 の内視鏡診断基準201に従って Risky Varices を選択し ているためであり門脈系のコンプライアンスの低下の 程度は出血歴のある症例と比較しても差はなく, 経過 をみれば胃十二指腸出血は同程度におこるものと考壳 られる。

今回の検討から長期予後をみると食道静脈瘤直達手 術は胃十二指腸出血率を増加させるものではないが胃 十二指腸出血に対する予防効果もないものと考古られ た。

選択的シャント術においては胃壁血行を門脈系と分 離し減圧をはかるため胃壁血行障害が少なく胃出血が 少ないとする報告むあるが21)，上述のごとく門脈圧え 進症研究会の集計ではむしろ直達手術よりる胃十二指 腸出血率は高い。

また内視鏡的硬化療法時にも合併症として胃炎出血 の頻度は高いが2222), 直達手術とは異なった, 胃壁血行 動態の変化が推測される。

食道静脈瘤患者の治療にあたっては，この胃十二指 腸出血を考慮しなければならない，現在のところ胃粘 膜保護剂や制酸凨などの投与や $\beta$ blocker ${ }^{18)}$ な゙の内 
科的治療が試みられているが十分ではなく21今後さら に術式などについても検討して行く必要があると思わ れる。

$$
\text { まとめ }
$$

1964年より1984年12月までの 21 年間に直達手術を施 行した食道静脈瘤症例473例中手術死亡その他を除く 441例につき術後胃十二指腸出血を検討した。累積胃十 二指腸出血率は 5 年 $9.7 \%, 10$ 年 $18.3 \%, 15$ 年 $20.1 \%$ で あったが，各直達手術間に有意差はなく，血行遮断の 範囲は術後長期の胃十二指腸出血率に影響をおよばさ ないものと考觉られた。

\section{文献}

1）小林迪夫：食道静脈瘤に対する外科治療の現況と 今後の問題点. 日外会誌 $83: 856-859,1982$

2) Mccormack TT, SIms J, Eyre-Brook I et al: Gastric lesions in portal hypertention, inflammatory gastritis or congenstive gastropathy. Gut $26: 1226-1232, \quad 1985$

3）置本幸弘：肝癌肝硬変その他の肝疾患に於ける胃 十二指腸の漬瘍性疾患の合併についての研究. 最 新医 $14: 1482-1500,1959$

4) Macray RS, Martin F, Amir-Ahmadi $\mathrm{H}$ et al: Erroneous diagnosis of hemorrhage from esophageal varices. Am J Dig Dis 14 : 755-760, 1969

5) Dagradi AE, Sanders D, Stempien SJ: The source of upper gastrointestinal bleeding in liver cirrhosis. Ann Intern Med $42: 852-855$, 1955

6）鎌田悌輔, 烟山 充, 小村旬三绕か：食道静脈瘤の 内視鏡所見判定基準に対する臨床的評価。肝臓 $20: 53-62,1979$

7) Palmer ED: Erosive gastritis in cirrhosis. influence of portal hypertention on the gastric mucosa. Am J Dig 2 : 31-36, 1957

8）加藤抱一, 二川俊二, 三條健昌活か: 実験的門脈圧 充進症の作製一胃酸分泌の変化. 肝臓 $19: 764$ $-769,1978$

9) Resnick RH, Iber FL, Ishihara AM et al: A controlled study of the therapeutic portacaval shunt. Gastroenterology $67: 843-857,1974$

10) Rueff B, Prandi D, Degos F et al: A controlled study of therapeutic portacaval shunt in cirrho. sis. Lancet $1: 655-659,1976$

11) Orloff MJ, Chandler JG, Anderman SJ et al : Gastric secretion and peptic ulcer following portocaval shunt in man. Ann Surg 170:515 $-526,1969$

12）出月康夫, 長田 功, 尾形正方ほか：経胸的食道離 断之門脈副血行路循環. 外科治療 $32: 232-240$, 1975

13) Delaney JP: Chronic alterations in gastrointestinal blood flow induced by vagotomy. Surgery $62: 155-158,1967$

14）梅北信孝, 出月康夫, 三條健昌注か：食道離断術後 早期胃炎出血例の検討. 臨外 $47: 326-330,1986$

15）河野彰文, 出月康夫, 渡辺 弘：食道静脈痹直達手 術前後の出血性胃十二指腸病変の内視鏡的検討. 臨外 45:1007-1015, 1984

16) Hassab MA: Gastroesophageal decongestive and splenectomy in the treatment of esophageal varices in bilihazial cirrhosis, further studies with a report on 355 operations. Surgery 61 : $169-176,1967$

17）加藤抱一：門脈圧六進症例における胃酸分泌。日 消病会誌 $76 ： 1427-1439,1979$

18) Lebrec D, Poynard T, hillon $P$ et al: Propranolol for prevention of recurrent gastrointestinal bleeding in patients with cirrhosis. $\mathrm{N}$ Engl J Med 305 : 1371-1374, 1981

19）川崎誠治, 梅北信孝, 渡邊五郎住か：肝外門脈閉塞 症の治療之予後. 厚生省特定疾患特発性門脈圧方 進症調査研究班昭和 56 年度研究報告書, 1981, p219 $-224$

20）井口 潔：食道静脈瘤内視鏡所見記載基準. 肝臓 $21: 779-783,1980$

21）芦田 寛, 伊藤信義, 石川羊男ほか：遠隔成績から み大食道静脈瘤手術の検討. 臨外 $43: 45-50$, 1982

22）梅北信孝, 出月康夫：食道静脈瘤に対する内視鏡 的硬化療法の予後. Gastroenterol Endosc 27： 2388-2389, 1985 